Marc Timmermans ${ }^{1}$

0000-0002-7660-3217

Institut d'Études Théologiques, Faculty SJ Brussels

\title{
Jesus and the Feminine Genius. The Anthropological Relevance of the Encounters of Jesus with Women in the Fourth Gospel
}

In 2018 we celebrate the $30^{\text {th }}$ anniversary of Jean Paul II's apostolic letter Mulieris Dignitatem, in which he introduces the term "feminine genius". ${ }^{2}$ It was at that time - as it still is now - necessary to defend and value women in the Church as well as in society. ${ }^{3}$ Nevertheless, the New Testament had already announced the equal dignity of man and woman. We can refer to the text of Paul: "There can be neither Jew nor Greek, there can be neither slave nor freeman, there can be neither

1 Dr. Marc Timmermans (The Netherlands *1964), member of the Emmanuel Community and priest of the diocese of s $\mathrm{s}$-Hertogenbosch, The Netherlands, teaches Moral Theology and Anthropology at the Jesuit theological faculty of Brussels (IET) and at the diocesan seminary of «s-Hertogenbosch. E-mail: m.timmermans@kpnmail.nl.

2 John Paul II, Apostolic Letter Mulieris Dignitatem (15.8.1988), no 31.

3 Cf. the disturbing article of M.-L. Kubacki, Il lavoro (quasi) gratuito delle suore, in the Vatican's Newspaper, “L'Osservatore Romano" (1.3.2018), http://www.osservatoreromano. $\mathrm{va}$ it/news/il-lavoro-quasi-gratuito-delle-suore (2.3.2018). 
male nor female -- for you are all one in Christ Jesus." (Ga 3:28) A real novelty in the culture of that time. ${ }^{4}$ A cultural revolution was announced, but it would not be until the 20th century that we could start reaping some fruits. Among others, Edith Stein and John Paul II have certainly contributed to advance the reflection on the actuality of this biblical message.

\section{Two leading ideas}

In this article we want to (re)discover the relevance of the attitude of Christ towards women for a theological anthropology. The fourth gospel relates several personal encounters between Jesus and a woman. These encounters reveal to us not only the benevolent look of Christ, but also a deep sense of what Edith Stein identified as the vocation of women or spiritual motherhood and what John Paul II called the feminine genius. ${ }^{5}$ The women Jesus encounters in this Gospel participate singularly in what the Italian scholar Damiano Marzotto pointed out as the fruitfulness of faith and the gathering in unity of the scattered children of God. ${ }^{6}$ Let's have a closer look to these two ideas.

\subsection{The fruitfulness of faith: life in Christ}

But to those who did accept him he gave power to become children of God, to those who believed in his name who were born not from human stock or human desire or human will but from God himself. (1:12-13)

4 Cf. H.B. Gerl-Falkovitz, Frau-Männin-Menschin. Zwischen Feminismus und Gender, Kevelaer 2009, p. 75

5 Cf. E. Stein, Die Frau. Fragestellungen und Reflexionen, Freiburg-Basel-Wien 20022, p. 61 and p. 54 (Edith Stein Gesamtausgabe, 13).

6 I owe to Damiano Marzotto the exegetical intuition of this feminine participation in the mission of Christ in terms of the fruitfulness of faith and the gathering of the scattered children of God. Cf. D. Marzotto, Pietro e Maddalena. Il Vangelo corre a due voci, Milano 2010, p. 39-57. 
Already in the Prologue (1:1-18), the evangelist presents the theme of 'generation': to become a child of God, to be begotten by the Father, means receiving life by faith in Jesus Christ. ${ }^{7}$ This theme is present through the entire gospel and will be solemnly resumed at the end in 20:31: "These are recorded so that you may believe that Jesus is the Christ, the Son of God, and that believing this you may have life through his name."

In his dialogue with Nicodemus, Jesus had already announced that this 'fruitfulness of faith' would be linked to his glorification on the cross: "the Son of man must be lifted up, so that everyone who believes have eternal life in him" (3:14-15). The believer must therefore "be born (literally: begotten) of water and the Spirit." (3:5) ${ }^{8}$ And in chapter 7, on the last day of the Feast of Tents (7:37-38), Jesus announces that streams of living water will flow from the heart of him who believes. The narrator tells us in the following verse that "He spoke of the Spirit". And he adds that the Spirit will be given only at the moment of the glorification of the Lord. Indeed, on the cross, he "delivered the Spirit" (19:30). Blood and water come out of his side (19:34). However, this glorification of Christ was not immediately understood by his disciples, because it arose through his condemnation and crucifixion. During the passion of Christ, Jesus is abandoned by almost all his friends. Yet, they cannot live without him. This is why Jesus announces, during the last supper, that they will look for him after his departure. ${ }^{9}$ But again, after the crucifixion and the death of the Lord, none of the disciples seems to have the desire or the courage to look for him, except a woman: Mary Magdalene. She is the only one to fulfill this word, to go out and look for Jesus. It resounds in the question of the Risen Lord: "Woman, [...] who are you looking for?" (20:15) As we can see, the fruitfulness of faith is first manifested by a woman. She looked for Jesus until she found him.

7 From $\gamma \varepsilon v v \alpha$ á $\omega$ : to beget, to bring forth.

8 In the dialogue with Nicodemus the verb to beget (үعvvów) occurs not less than 8 times between 3:3 and 3:8. It expresses the access to new life through faith. The important dialogue with Nicodemus links the verb to beget with faith in Christ and new life through the Holy Spirit and already points out to the glorification on the cross where it will be realized.

9 "Little children, I shall be with you only a little longer. You will look for me." (13:33) 


\subsection{Gather in unity the scattered children of God}

One of the central missions of Jesus is revealed by the High Priest Caiaphas (11:51): "He was prophesying that Jesus was to die for the nation." And the narrator adds (11:52): "and not for the nation only but also in order to gather into one the scattered children of God." In a particular way, as we will see, the mother of Jesus is taking part in this mission of "gathering the scattered children of God'. And this seems to be the case as well with the other women in the gospel, especially the Samaritan woman and the two sisters of Bethany: Martha and Mary. This gathering of the scattered children of God is closely related to the fruitfulness of faith that the prologue suggests: will become children of God those who "believe in his name"; they are "born from God." (1:12-13) And these children of the Father are called to remain united in Jesus, just like the branches that will not bear fruit unless they remain in the Vine (15:6). We will see that this unification includes not only Jews, but everyone who will come to faith in Christ. The perspective of salvation in the Fourth Gospel is clearly universal.

\section{The Encounters of Jesus with Women in the Fourth Gospel}

Let us now review more closely those passages in the Gospel where Jesus is in dialogue with a woman, to verify in these encounters the link between the fruitfulness of faith and the begetting of God in Jesus' mission and to identify the specific role of women. ${ }^{10}$

\subsection{Mary in Cana (2:1-12)}

The fourth gospel is taken in a great inclusion between, on the one hand, the scene of Cana and, on the other, the crucifixion, with in both

10 Jesus calls 'woman' (gunhv, vocative: guvnai) his mother in 2:4 et and 19:26; the Samaritan woman in 4:21; the adulterous woman in 8:10 and Mary Magdalene in 20:13 and 20:15. The two sisters of Bethany (in the chapters 11 and 12) are not called in this way. Let's notice that the only woman to be called by her own name is Mary Magdalene in 20:16. 
scenes the presence of the mother of Jesus. At both occasions he calls her 'woman'. ${ }^{11}$ By the mention of the third day (2:1), the evangelist seems to put this event in connection with the gift of the Torah on Mount Sinai and therefore with the paschal mystery, the Exodus of the Jewish people, but also, of course the resurrection of Jesus on the third day. ${ }^{12}$ Jesus manifests in Cana his glory by giving the new wine, symbol of the new covenant with a new law. This "sign" occurs right after the word of his mother to the servants: "Do whatever he tells you!" (2:5). At Mount Sinai, the manifestation of glory comes after the declaration of their availability by the Hebrew people: "Whatever the Lord has said, we will do" (Ex 19:8). Moreover, in the Old Testament, Israel is often portrayed as the bride of the Lord, as his spouse. In the account of the wedding in Cana, there's no mention of the names of the bride or the groom, only that Jesus, his disciples and his mother were present. In this context Jesus said to his mother, "What about me and you, woman? My hour has not yet come." (2:4, literal translation) Who are the bride and groom and what is meant here with 'hour'? We can understand this mention of the hour in two ways. Either as an affirmation: 'my hour has not come yet'; the sign of the transformation of water into wine points out to the glorification on the cross, the hour in which all will be accomplished. (19:30) Or as a question: 'my hour hasn't come yet?'; this would imply that the hour begins at this very moment, even if it's not yet fully come, and it will continue to be manifested throughout the public life of Jesus, even if it's only fully accomplished on the cross. The public life of Jesus is part of the accomplishment and the sign in Cana was the beginning of the signs. (2:11) In this last case, the intervention and the availability of Mary can be understood as a provocation of the action of Jesus. Therefore, since the purpose of Jesus' sign is to bring about faith, it is plausible to recognize in Mary the bride of Christ and also the mother of believers, to the extent that she introduces the action of Christ that

$11 \quad 2: 4$ et 19:26.

12 Cf. Ex 19:1, where it's about the third month: "Three months to the day after leaving Egypt...". The mention of the third day appears in Ex 19:15 where the coming theophany is announced: "Be ready for the third day." Cf. Jn 20:1 with the event of the resurrection on the "first day of the week", the third day since the crucifixion on Friday. 
brings out faith. ${ }^{13}$ In this passage of the wedding of Cana, we discern a movement, initiated by the mother of Jesus. Throughout the gospel, this movement will lead in the end "to the manifestation of glory, to faith in Jesus and to gather those who believe in him (Jesus)". ${ }^{14}$

Mary's intervention seems decisive in Cana. Her role is also intrinsically linked to her femininity. She is like the spokesperson for Israel, the spouse of the Lord, who is in need ("they have no more wine"). ${ }^{15}$ By her availability to the word of God, to the salvific work of Christ, she allows the best wine to be given to humanity. Through her intercession, Christ manifests his glory. The sign of Cana, the first sign, is also the first gathering of the scattered children of God. Indeed, immediately after the Cana event, the community of believers sets out: "After that, he went down to Capernaum, he, his mother and his brothers and his disciples." (2:12)

\subsection{The Samaritan woman (4:4-42)}

In the fourth chapter Jesus enters into dialogue with the Samaritan woman. As it was the case for the mother of Jesus in Cana, the femininity of the Samaritan woman is important in this passage. Here again 'a woman' plays a decisive role in the process of salvation that's taking place near the source of Sychar, in Samaria, on non-Jewish territory.

After the verses of transitions (4:4-6), this passage is divided in two parts, the one where Jesus is alone with the woman (4:7-26) and the other where the disciples join Jesus at the moment that the woman goes back to town (4:27-42). In the first part we see a progressive revelation in both directions. The more Jesus reveals to her who she is and what she did, she discovers more and more his identity, expressed in a sequence of specific determinations: he is "Jewish" (4:9), "greater than Jacob" (4:12), the one who gives the water that becomes "spring of water welling up to eternal

13 There is clearly a "strategy of faith" in the fourth Gospel. Cf. P. Monnier, Jésus ressuscité, le prophète plus grand que Moïse. Lecture de Jn 21, 1-14, „Nouvelle Revue Théologique” [NRT] 139 (2017), p. 9.

14 D. Marzotto, Pietro e Maddalena. Il Vangelo corre a due voci, op. cit., p. 44.

15 Cf. X. Leon-Dufour, Lecture de l'évangile selon Jean, vol. 1, Paris 1988, p. 226. 
life" (4:14), "prophet" (4:19) and finally "Messiah" (4:25). The consistent merciful attitude of Jesus makes it possible for the woman to overcome shame and humiliation. In the second part, we gather the fruits of this revelation and the fruits of the reception that the woman has made of it: the evangelization of the inhabitants of the city to whom the woman went to testify of her discovery by saying: "could he be the Christ?" (4:29) she bears witness to them and leads them to Jesus.

Between the moment the inhabitants of Sychar left their city (4:30) and their arrival near the well (4:40), there is the very significant discourse of Jesus about the harvest and the gathering "of the fruit for eternal life" (4:36). Jesus invites his disciples to "lift up the eyes and see", because "the fields are ready for the harvest" (4:35), like the prophets Isaiah and Baruch, who announced the gathering of all the scattered children of God (Is 49:18; 60:4; Bar 5:5-6). For this is what Christ seeks to do. This is his mission. He calls it his "food" (4:34): the work of the Father, the one who sent him. ${ }^{16}$ The dialogue with the woman which surprises the disciples and the meeting with the inhabitants of the city; all this is part of the work of the Father that Christ is accomplishing.

Clearly, what is at stake here is the fact that salvation is offered not only to the Jews, but also to the Gentiles. That's why Jesus is explicitly recognized as "indeed the Saviour of the world" (4:42). And it is through the action of the woman, her initiative and her testimony, that her fellow citizens start their journey of faith in Jesus. They represent the first fruits of the great eschatological harvest, the gathering of those who believe in Jesus (4:39: "Many of that town believed in him").

\subsection{The adulterous woman (8:1-11)}

The pericope of the adulterous woman raises questions ${ }^{17}$ This passage is probably inserted later, but its significance at this place in the gospel seems totally justified. Indeed, two concepts at the beginning and at the end of the chapter represent an inclusion. They suggest it's unity and

16 D. Marzotto, Pietro e Maddalena. Il Vangelo corre a due voci, op. cit., p. 45.

17 Cf. Y. Simoens, Selon Jean. 2. Une interprétation, Bruxelles 1997, p. 361-362. 
coherence. At both ends of the chapter, the temple is mentioned ( $8: 2$ and 8:59), but also the threat of stoning (8:7 and 8:59). More explicit and convincing are the words of Jesus to the Pharisees in 8:15: "You judge by human standards (literally: by the flesh), I judge no one." The passage of the adulterous woman may very well have been inserted to illustrate this affirmation of Christ.

The story begins when Jesus returns from a night of prayer on the Mount of Olives (8:1). He goes down to Jerusalem to teach in the temple in front of "all the people" (8:2). At that moment the scribes and Pharisees come to him bringing with them a woman caught in the act of adultery. And according to the Law, she should be stoned. ${ }^{18}$ "She is virtually condemned and Jesus is apparently solicited only for simple advice: 'And you, what do you say?' In fact, it seems that the Pharisees literally hope to kill two birds with one stone: the woman in the end doesn't really interest them, but if she allows them to stone Jesus!"19 Jesus' answer is unexpected. He remains silent first and then, while bending over, he writes on the ground.

Now this is the only time in the four gospels where Jesus actually writes something and no one could tell us what he was writing. Obviously, it is the gesture and the silence that accompanies it that really matter. He is the new lawmaker, who writes the Tables of the Law with his finger, just as God wrote the tables of the covenant with his finger. (Ex 31:18) We can imagine the growing malaise of the accusers. The silence thus prepares the surprising statement of Jesus: "let him who is without sin cast the first stone at her" (8:7), followed by a new gesture of writing in silence. When asked about the Law, Jesus responds by recourse to the Law, as it is written in Deuteronomy: "The witnesses will put the first hand to the execution of the condemned, then all the people will put their hand." (Dt 17:7) We see how Jesus interprets this verse of the Law. The only true witness for him is one who is sinless. Only a pure of heart is able to discover in the letter of the Law the

18 Cf. Dt 22:22: "If a man is caught having sexual intercourse with another man's wife, both must be put to death: the man who has slept with her and the woman herself."

19 F. Quéré, Les femmes de l'évangile, Paris 1982, p. 23. 
loving plan of the God of life. For God does not want the sinner's death, says the prophet Ezekiel, but his life. ${ }^{20}$ In fact, Jesus himself is the only true witness. He's the one sent by God. He alone is worthy of lifting the apparent contradiction found in the Law. And he doesn't judge: "I judge no one". (8:15)

While the gesture of Jesus refers to the Tables of the Law, the soft sand of mercy contrasts with the hardness of the stone. However, at first sight Jesus seems to confirm the execution, he apparently allows stoning. And yet the lynching will not take place because Jesus knew what he was doing: he "knew what was in the man." (2:25) Probably the main reason why the accusers withdrew, was because they could not condemn Jesus. And that was their main goal. But certainly, they must have felt uncomfortable as well in their role as witnesses. ${ }^{21}$

At the end of this passage, Jesus is again alone with a woman..$^{22}$ She is, like the Samaritan woman, confronted with her sin. Like the other woman, she is not condemned. But this time there is not a beautiful encounter, no word of revelation, not even a sign of gratitude from the woman to the one who delivered her from the hands of her accusers by risking his own life. ${ }^{23}$ "Jesus gives her back her freedom. It's now up to her to regain her innocence." ${ }^{4}$

Then he speaks to her: "Woman, where are they? Nobody condemned you?" (8:10) Very discreetly, we are able to hear what might be seen as a beginning of faith in the only sentence of this humiliated woman: "Nobody, Lord" (8:11) As if she said: 'I know that no one has condemned me and I believe that you will not condemn me either, Lord'. She will then be able to internalize the mercy filled words of the Lord: "Neither do I condemn you, but go, (and) from now on, sin no more" (8:11). The curious absence of the man who was guilty with her, leaves the place

Ez 33:11. Cf. Dt 30:19.

${ }^{21}$ Being a spectator at an act of adultery and being without sin, is a rather unlikely combination.

22 Cf. 4:7-25, where Jesus is alone with the Samaritan woman.

23 P. Lefebvre et V. de Montalambert, Un homme, une femme et Dieu, Paris 2007, p. 231-233.

24 F. Quéré, Les femmes de l'évangile, op. cit., p. 30. 
open to the one who calls her 'woman'. ${ }^{25}$ Here again, Jesus is the man in front of the woman, like the groom in front of the bride.

Indeed, on a symbolic level, which is never absent in the Fourth Gospel, the adulterous woman represents the unfaithful bride of the old Testament, but also the sinner of every moment in history. As such, she encounters mercy in the person of the Merciful, he who is "the light of the world" (8:12), who "enlightens every man" (1:9). Indeed, Jesus proposes himself as the principle (of interpretation) of the law. The woman, who has just come out of the darkness of sin, hearing the liberating truth (8:32), will now be able to walk in the light. Her life contradicted faith. She was a lost child of God, scattered. Thus, she can be both an example and a confirmation of the victory over sin and death by him who is merciful, i.e. to be begotten in faith and to regain her dignity as a child of God.

\subsection{Martha and Mary (11:1-44)}

At Cana the intercession of a woman was important. She allowed or even provoked the 'first sign'. The sign of the raising of Lazarus is at the other end of the first part of the Gospel, which is commonly called the book of signs (chapter 1-12). Here again the role of a woman, or in this case two women, shows to be of great importance. The hour of glorification approaches and Jesus is now threatened with death. The disciples want to warn him: "Rabbi, they were seeking to stone you" (11:8). And their fear is justified: the Sanhedrin meets after the raising of Lazarus, because this sign has aroused the faith of many (11:45). The verdict of the High Priest is clear: "One man should die for the people" (11:50). The narrator adds, as we have already mentioned, that the death of Christ will also allow "to gather the scattered children of God" (11:52).

25 Y. Simoens, Selon Jean. 2. Une interprétation, op. cit., p. 376. Simoens links this encounter with the one Jesus will have with Mary Magdalene. "He says to her: 'woman!' He calls her his woman with such a royal gesture, such a priestly rightness, such a prophetic efficiency. While waiting for the ultimate confidences of the sort to Mary Magdalene, who is in search for her beloved one: 'Woman!' (20:13.15) 
Caiaphas prophesizes in the name of the Jewish people; the narrator enlarges the perspective of salvation to its universal dimension.

Between the two mentions of death threat, some dramatic scenes take place, with the figures of Martha (11:17-27) and Mary (11:28-37) and the raising of Lazarus (11:38-44). The structure of this passage allows us to understand the meaning of these events. They refer to a larger and more important event: the death and resurrection of Jesus himself. Jesus had already announced at the beginning of the chapter that the sickness of Lazarus would not end in death. "It is for God's glory, so that through it the Son of God may be glorified." (11:4) In fact, it is Jesus who is threatened. First implicitly and later explicitly by Caiaphas, his death is announced. Indeed, he will die not just for Lazarus, but for the people and for all the scattered children of God. He is, as he says to Martha, "the resurrection and the life, whoever believes (in him), even if he dies, will live." (11:25)

Surely, Martha and Mary cannot imagine that Jesus will raise their brother of the tomb. Isn't it already the fourth day since he died? There is nothing left to hope for. However, their intercession does provoke the action of Christ: "Lord, if you had been here, my brother would not have died." (11:21, said by Martha and 11:32, from the mouth of Mary). Between the two occurrences of this same sentence, at the heart of our passage, is the magnificent act of faith of Martha: "Yes, Lord, I believe that you are the Christ, the Son of God who comes into the world." (11:27) Just as it was the case with the mother of Jesus in Cana, their intercession is not a program or demand to which Jesus must respond to, but an act of faith.

This intercession of the two sisters has a double effect. First, Martha and Mary appeal to Jesus and Jesus responds with the raising of Lazarus, a sign that anticipates his own death and resurrection for the salvation of the world. But, in the next moment, the events that follow the call of the two women provoke the reaction of the Sanhedrin and their decision that Jesus should die for the people, so that he may gather the scattered children of God. The faith of the two women, in a certain way, accelerates the accomplishment of the work of salvation. They saw the glory of God manifested, because they believed (11:40). Verse 
19 states that "many of the Jews" came to Martha and Mary to comfort them. In verse 45 we read that "many of the Jews" who came to Mary believed in Jesus. In the meantime, she had led them to Jesus because they were following her. Thanks to her, instead of arriving at the tomb, the place of death, they found the Lord (11:31-32), the one who is the resurrection and the life. The comforters became believers. Here again, a woman (or in this case two women) prepares the access to faith of men. In this passage, the women are a singular instrument in the salvific work of Christ. Again, a 'woman' participates formally and decisively in his mission.

\subsection{The anointing at Bethany (12:1-8)}

The consequences of the event of the raising of Lazarus are felt in chapter 12 of our gospel. If we put aside the epilogue (12:36b-50), we can discern two parts in this chapter: 12:1-19 and 12:20-36a. In the first part Jesus is designated as the King of Israel (12:13), while in the second part is mentioned his universal reign: "When I am lifted up from the earth, I will draw all to myself" (12:32), which is confirmed by the sudden appearance of the Greek at the beginning of this part (12:20). Inside the periscope of 12:1-19, we can identify two scenes: the anointing in 12:1-11 that points to the death of Christ, and the royal entrance in 12:12-19, which anticipates his glorification.

Mary's anointing in Bethany is a prophetic gesture by which she indicates the inestimable price and the superabundant value of Jesus' imminent death. ${ }^{26}$ The scent of pure nard (12:3) contrasts with the smell of death of Lazarus (11:39). Judas' critical remark about the waste of money seems not only to be a contrast to Mary's good intention with Judas' bad intention, but also, in a certain way, Judas' rational and calculative masculine argumentation with the madness of love, the sense of value and the gratuitousness and feminine abundance of Mary, which reminds us of the sign of Cana in presence of the other Mary. At the wedding, the master of the feast was astonished about the order in which the wines

26 D. Marzotto, Pietro e Maddalena. Il Vangelo corre a due voci, op. cit., p. 49. 
were served (2:10). Indeed, it is a folly to serve the grand $\mathrm{cru}$ to people who are no longer in a state to appreciate its quality. However, this logic of profusion is a characteristic of the ministry of Jesus, who came to give life in abundance (10:10) ${ }^{27}$

Our passage ends with another mention by the narrator that many Jews believed in Jesus because of Lazarus (12:11). As we already saw, the sign of the raising has aroused the faith of many Jews. At the same time, it made the authorities understand that Lazarus himself, as a 'living sign', was a threat and that he should be killed too. This passage is therefore closely linked to the unveiling of Christ's identity, his imminent death and the threat of death to those around him. But what is the role of Mary in all this and what is the meaning of her gesture?

To better grasp this meaning, we will have to notice, with Marzotto, the parallel between the anointing of Bethany and the washing of the feet in the next chapter (13:2-20). ${ }^{28}$ Several indications confirm this parallel. In both cases, the gestures take place at a banquet (dei'pnon, in 12:2 and 13:2), in the days preceding the Passover (mentioned in 12:1 and 13:1). There is also mention of the "feet", the verb "to wipe" and the presence of Judas Iscariot, "the one who would betray him" (12:4), "the devil had put into the mind of Judas [...] to betray him" (13:2). Moreover, in both cases Jesus must explain or justify the gesture: to Judas about the anointing and to Peter about the washing of the feet. Mary did this, he said to Judas, in view of his burial (12:7). Peter will know after that, what he does not know now (13:7). Both cases taken together, Jesus refers to his death and glorification. Mary therefore anticipates the prophetic gesture of Jesus, in its dimension of humble fraternal service and its prophetic dimension. The two gestures together prefigure the death and resurrection of Christ for the salvation of the world. ${ }^{29}$

The abundance of the love that Christ will manifest on the cross is prefigured by the gesture of Mary. She thus participates, through charity

27 Cf. also 6:12: "When they had eaten enough he said to the disciples, "Pick up the pieces left over, so that nothing is wasted. So, they picked them up and filled twelve large baskets with scraps left over from the meal of five barley loaves."

28 Cf. D. Marzotto, Pietro e Maddalena. Il Vangelo corre a due voci, op. cit., p. 49-52.

29 D. Marzotto, Pietro e Maddalena. Il Vangelo corre a due voci, op. cit., p. 51. 
and humility, in the salvific work of the Lord. She opens the perspective on the events to come. "Mary has the intuition of the greatness of the mystery of Christ and by his particular gesture, she manifests its singularity." 30 She plays her role in the unfolding of the salvific and universal mission of Jesus by anticipating its fulfilment with a gesture of great symbolic value: an unction that fills the whole house with its perfume. "When I'm lifted up from the earth, I shall draw all to myself." (12:32)

\subsection{Mary near the cross (Jn 19:25-27)}

"Having loved those who were his in the world, he loved them to the end" (13:1), giving his life on the cross, delivering the Spirit, Jesus fulfils the Scripture: "After this, Jesus knew that everything had now been completed and, so that the scripture should be completely fulfilled, he said: I am thirsty. [...] After Jesus had taken the vinegar he said, 'It is fulfilled'; and bowing his head he gave up his spirit." (19:28-30) The seamless tunic that will not be torn (19:23-24) and the legs that will not be broken (19:33) are signs of this unity in Christ. They refer to Psalm 22 and several texts of the Old Testament about the paschal lamb. ${ }^{32}$

We thus see that the fulfilment of Scripture on the cross refers to this mission of bringing together in unity the children of God and give birth to new life through faith in Christ. Water and blood testify to this new life. At the foot of the cross, Mary, the mother-woman, welcomes the beloved disciple and, in him, all those who will believe in her Son. ${ }^{33}$ In her are fulfilled the prophecies concerning Jerusalem,

30 D. Marzotto, Pietro e Maddalena. Il Vangelo corre a due voci, op. cit., p. 52.

31 D. Marzotto, Pietro e Maddalena. Il Vangelo corre a due voci, op. cit., p. 52.

32 Thirst: cf. Ps 22:16: “" My mouth is dry as earthenware, my tongue sticks to my jaw"; Ps 69:22: "They gave me vinegar to drink when I was thirsty." B o n e s: cf. Ex 12:46 and $\mathrm{Nb}$ 9:12: "Nor will they break any of its bones [...] following the entire Passover ritual." The mention of the hyssop stick, on which the sponge that was soaked in vinegar was put, also refers to the 'saving' blood of the pascal lamb (Ex 12:22): "Then take a bunch of hyssop, dip it in the blood that is in the basin, and with the blood from the basin touch the lintel and both door-posts."

33 M. Gourgues, Marie, la 'femme' et la 'mère' en Jean, NRT 108 (1986), p. 188-189. 
'the mother': (Jerusalem) "the nations will come to your light, and kings to your dawning brightness. Lift up your eyes and look around, all are gathered and coming towards you, your sons coming from far away and your daughters being carried on the hip." (Is 60:3-4) 34 $^{34}$ In the verse before, the prophet announces that the glory of the Lord will rise on her (Jerusalem). This glory of the Lord is spread out on Jerusalem, the mother. Indeed, the hour of the cross is the hour of glorification. It's the hour of the glory of the Lord..$^{35}$ This glory also descends on her who is the mother of Jesus: the woman at the foot of the cross who becomes the mother of the beloved disciple and all believers. To his mother, he said: „Woman here is your son" (19:26) and to the disciple: "here is your mother." (19:27) We must notice that, according to the testimony of Matthew (27:56), the mother of the apostle John, the wife of Zebedee, was present at the foot of the cross. If, historically, the beloved disciple is this same apostle John, his mother must have suffered from these words of Jesus. Evidently, what's at stake goes beyond the scope of natural parentage or adoption. In welcoming the mother, the disciple "welcomes Christ, especially as he fulfils his work of bringing men together." ${ }^{\prime 36} \mathrm{At}$ the cross, the idea of filiation and maternity reveals the birth to a new life, into a new Covenant, through new relationships. In the image of the tunic woven from above, it is a motherhood which is revealed 'from above' that will gather in the unity of filiation the scattered disciples. ${ }^{37}$

This new Covenant is the fulfilment of the Covenant with Israel and at the same time the opening of this Covenant to the universal dimensions of all humanity, of all the scattered children of God. In Cana, Mary

${ }^{34}$ Cf. Ba 4:36-37, where it's rather about the return of the exiled of the people of Israel: "Jerusalem, [...] look, the children you watched go away are on their way home; reassembled from east and west, they are on their way home at the Holy One's command, rejoicing in God's glory."

35 In the background of this passage we must read the prophecy of Isaiah 66:5-7: "Let YHWH show his glory [...] A voice from the Temple! [...] Before being in labour she has given birth. Before the birth pangs came, she has been delivered of a child."

36 D. Marzotto, Pietro e Maddalena. Il Vangelo corre a due voci, op. cit., p. 42.

37 Cf. Jn 16:21: "A woman in childbirth suffers, because her time has come; but when she has given birth to the child she forgets the suffering in her joy that a human being has been born into the world." 
is above all the bride. Here Mary is the mother, the new Jerusalem, the mother of all the scattered children who come from the ends of the earth to enter this new unit of believers. When Jesus at the very moment of the accomplishment of Scripture expresses his thirst, he expresses the thirst of the God of the covenant for the love of his people. And all he receives is vinegar, spoiled wine, sign of our unfaithfulness and sin. However, through the presence of Mary, we know that something else is already prepared: the excellent wine of the new Covenant, sign of purity and divine happiness: "Blessed (happy) are those who are invited to the marriage supper of the Lamb." (Rev 19:9) ${ }^{38}$

\subsection{Mary Magdalene and the Risen Lord (20:1-2.11-18)}

Like the Samaritan woman, who came to the well for an unexpected encounter with Christ, Mary Magdalene comes to the tomb to meet unexpectedly, not the dead man she was looking for, but the Risen One. Like the Samaritan woman who does not hesitate to bear witness of her encounter with Jesus, Mary will also return to testify of the resurrection of Christ to his brothers.

She is the first to arrive at the tomb. She does not enter but goes back to get Peter and 'the other disciple'. They both went into the tomb. Peter looks inside and ascertains a situation, the other disciple "sees and believes” (20:8). Here again, 'the woman', in this case Mary Magdalene, initiates a journey of faith. Through her the disciples come to believe. She's therefore rightly called "Apostola apostolorum". ${ }^{39}$

The encounter with the Risen One makes Madeleine the privileged messenger to announce the good news. To the one she thinks to be the 'gardener' she confesses that she still desires to "take away" the Lord $(20: 15)$. After the revelation of the Lord who calls her by her name, she converts, she literally turns around (20:16). She knows now that she cannot keep Jesus for herself, as she seemed to desire initially. She has changed. So, Jesus sends her on a mission to announce the good news

38 Makópıro: the accomplishment of all happiness.

39 Cf. Thomas Aquinas, Expositio in evangelium Joannis. c. XX, L. III, 6. 
to the brothers (20:17-18). This concept of 'brothers', refers to the prologue, to the fraternity of believers who are born (begotten) from God. $(1: 13)$

The mission of Jesus has come to an end, the brothers (and sisters) have to take it over. A transmission has to take place. And this is the message that Jesus asks her to transmit: 'My Father is your Father; my God is your God' (20:17). In other words: 'if you believe, you will be like the only begotten son of the father, you will be begotten from God.' Mary Magdalene mediates this transmission from Jesus to the brothers. Thus, we ascertain that she is closely and singularly associated with the work of generation of which the prologue speaks.

Apart from that, what will she tell the brothers? Having recognized the voice of the Good Shepherd who calls her by her name (20:16, cf. 10:3), she can testify to the disciples: "I have seen the Lord." (20:18) This announcement, on the one hand, echoes the announcement of Andrew to his brother Simon at the beginning of the Gospel (1:41): "we have found the Messiah", and, on the other hand, it prepares the testimony of the disciples before Thomas (20:25): "We have seen the Lord." The word of Mary Magdalene reminds us as well of the Samaritan woman who said to the inhabitants of the city: "Come, see a man, who has told me everything I have done; could this be the Christ?" (4:29)

By her initiative, by the testimony of 'the Apostle of the Apostles', the disciples are, so to speak, 'regenerated to faith': "blessed are those who have not seen and yet believe." (20:29) And the narrator concludes that all this has been said and written "so that believing this you might have life in his name." (20:31) At her initiative, Peter and the beloved disciple came to the empty tomb. Therefore, in the fourth Gospel, this generation to faith appears particularly fruitful through the mediation of women: the mother of Jesus, the Samaritan woman, Martha, her sister Mary or Mary Magdalene. I suppose that this was the case for most of us. The transmission of faith passes especially and above all by the mothers. 


\section{The feminine genius and the mission of Christ}

From Cana to the death and resurrection of Jesus, 'the woman' plays a determining role in the process of Salvation, which unfolds in the fourth Gospel. In Cana, the mother of Jesus unleashed the first movement of gathering the believers around Jesus. The Samaritan woman was able to bring to Jesus, the Saviour of the world, the first fruits of the eschatological harvest. She introduced her fellow citizens to faith in Jesus through her testimony and led them to Jesus. Similarly, Martha and Mary have somehow accelerated the fulfilment of the events of Salvation and the manifestation of glory by unleashing the movement of faith in Jesus. Martha also precede in faith her fellow-citizens, by expressing with her sister their attachment to the Lord and by her faith in him when she confesses that he is the Son of God who had to come into the world. Like the mother of Jesus who opened the way to Jesus to manifest his glory, by her concern about the lack of wine at the wedding, Mary of Bethany opened the way with her fragrant anointing to the washing of the feet of the disciples by the Lord. So, we cannot but take notice that the ministry of Christ is inspired and sometimes even initiated by women.

What does this feminine presence mean in the ministry of Jesus? Through the passages we have studied, we can see a dual function of the woman in the fourth Gospel. She plays a role of provocation and anticipation. On the one hand, as it is the case in "Cana, at the well of Sychar and in Bethany, she provokes, leads, and helps Jesus to manifest his glory." ${ }^{40}$ Or, in the case of the adulterous woman, to allow Jesus to enlighten the life and the conscience of those who expect his judgment. In fact, his judgment consists in being the light of the world, which illuminates everyone. On the other hand, 'the woman' "anticipates the gift of self, which is the core of the paschal mystery of Jesus (at Cana, but also at the banquet of Bethany)." And not just that, because "the woman is also the first to embark on a path of faith, on which others will follow her." ${ }^{41}$ 
At the same time, we have mentioned that, at least at two occasions, a woman has taken a different stand in front of the Lord than a man. The master of the feast at Cana and Judas at Bethany were blinded by their reductive and calculative rationalization. The interventions of the mother of Jesus at Cana and Mary of Bethany concern the purely gratuitous, superfluous and highly symbolic actions of Jesus, while most of the signs he accomplishes in the Gospel correspond to a primary and urgent human need: disease (4:46ss; 5:1ss), hunger (6:1ss) and blindness (9:1ss). As if women understand by intuition that the order of grace exceeds that of nature.

In addition, we have seen, especially in Cana and at the occasion of the illness of Lazarus, that the persistent intervention of a woman seems to disturb, disrupt the agenda of Jesus by pushing him, after a moment of hesitation, to change his program. "But it is precisely from this sudden change that new life is born." ${ }^{42}$

Finally, the different figures of the woman, which we have presented, singularly illuminate the role of the one who is 'the woman' par excellence in the fourth Gospel and who exercises a unique function before Christ: the one who is called 'his mother'. On the cross, Jesus can say to his mother 'woman' and 'this is your son'. Within the mission of Christ to allow the scattered children of the Father to be gathered in unity of faith and receiving new life, she (the mother) gives birth to the disciple whom Jesus loved and who represents all the believers, the community of new life through faith in him. In Cana, Mary is at the initiative of the sign which is the prefiguration of the gift of life that Jesus was going to give in abundance. Through her intervention in Cana, Mary prepared in great confidence towards her son the anticipation of his glorification. Her intervention can be seen as the beginning of the coming of his hour. Through her presence 'near the cross', she takes part in the full reality of the manifestation of the glory of her son. In Mary, the spouse and mother, the prophecies about Jerusalem are fulfilled. In her, the bride and mother, the new Covenant sees the day.

\footnotetext{
42 D. Marzotto, Pietro e Maddalena. Il Vangelo corre a due voci, op. cit., p. 55.
} 
The words of Jesus: 'this is your son' and 'this is your mother' mean that the gathering of the scattered children of God, which he will realize by drawing all to him, is also fulfilled through his mother. „In reality, if the Prologue speaks of the need to welcome Jesus Christ by becoming children of God, here the beloved disciple welcomes in his intimacy the mother of Jesus. The bond that associates Jesus and 'the woman' could not be expressed deeper way." 43

This bond that unites Jesus and Mary, at the moment of crucifixion, is properly a spousal bond. It announces a great fruitfulness, that of all the children of God who are going to be begotten to faith. At the foot of the cross, unlike the wedding of Cana, Mary says nothing. She does not speak. Her mission to accompany her son is accomplished, a new mission is entrusted to her. From now on, she will be the mother of the believers, the one who will never cease to engender, protect, console and strengthen her children, the ones that Jesus will entrust to her, and to bring them back to him with a maternal hand.

\subsection{Edith Stein: Spiritual Motherhood}

On several occasions, Edith Stein speaks of a particular task that a woman is brought to exercise: that of spiritual motherhood. ${ }^{44}$ "The title of Mary as our mother is not merely symbolic. Mary is our mother in the most real and lofty sense, a sense which surpasses that of earthly maternity. She begot our life of grace for us because she offered up her entire being, body and soul, as the Mother of God." ${ }^{45}$ She then carries out this spiritual accompaniment because she is in the image of God who is also Father. ${ }^{46}$ Religious sisters and consecrated women may recognize in the exercise of spiritual motherhood a specific way of putting into practice their surrender to God. ${ }^{47}$

44 E. Stein, Die Frau. Fragestellungen und Reflexionen, op. cit., p. 54; p. 78; p. 104 and p. 112.

45 E. Stein, Die Frau. Fragestellungen und Reflexionen, op. cit., p. 212.

46 E. Stein, Die Frau. Fragestellungen und Reflexionen, op. cit., p. 78.

47 E. Stein, Die Frau. Fragestellungen und Reflexionen, op. cit., p. 104.
} 
What does this spiritual motherhood mean? It consists in the fact that a woman accompanies and forms children of God in view of the Kingdom of God. These children may be of all ages. They can be adults, as we've seen in the Gospel. It is a spiritual task with a spiritual purpose. "To arouse children for heaven is a true motherhood - a spiritual motherhood that is independent of physical maternity." ${ }^{48}$

\subsection{John Paul II: feminine genius}

This maternal function of 'the woman', of the mother of Jesus does not stop at the cross. It is permanent. It corresponds to the feminine genius and represents a call for all women in history. The most beautiful illustration is given by Marie Magdalene. She was, as John Paul II put it, "before the apostles, the eyewitness of the risen Christ, and for this reason she was also the first to bear witness before the Apostles. And this event, in a sense, is like the crowning of all that has been said about Christ's transmission of divine truth to women, on an equal footing with men." 49

The feminine genius is expressed in the Gospel by a profound intuition of the mystery of salvation that is manifesting itself, by the more spontaneous reception (in comparison to men) of the word of the Lord, by the attention to the needs of the people, by the force to anticipate, even to provoke the action of Christ for the sake of Salvation and by the openness to the universal dimension of Salvation beyond the limits codified by the law. In short, 'the woman', any woman, in the image of the mother of Jesus and with her, is the eminent partner for Christ in his work of salvation, that he accomplishes in union with the Father: to give new life to those who believe and to gather the scattered children of God..$^{50}$

48 E. Stein, Die Frau. Fragestellungen und Reflexionen, op. cit., p. 54.

49 John-Paul II, Apostolic Letter Mulieris Dignitatem (15.8.1988), no 16.

50 This participation in Jesus' mission of salvation sheds a singular light on the feminine participation in the (common) priesthood. Cf. J.-M. Hennaux, Le sacerdoce. Humain et divin, masculine et féminin, Paris 2018 (Cahiers de la NRT), p. 103: "In Mary, the theological meaning of femininity is revealed. The woman is a Marian symbol, symbol of a universal fecundity in Christ, exceeding time, entering eternity. For the same reason, Christ couldn't limit her 


\section{Conclusion}

The moment has come that the Church must rediscover the need for the feminine genius through an active participation of women in the community of believers. It's therefore time to encourage women to fill the unique space in the ranks of the Church that are designed for them. It demands an active attitude from all men in the church, especially those who are in a hierarchical position, to allow women to take their place, to express themselves and to listen to what the Spirit tells to the Church through each one of them. The importance is great for the Church and vital for each of her members. It is to her, the woman, said John Paul II, that God has entrusted the human person in a particular way. ${ }^{51}$

to a function, be it the ministerial priesthood. She symbolizes the common and eternal priesthood, which is always at the source of the ministerial priesthood."

${ }^{51}$ John-Paul II, Apostolic Letter Mulieris Dignitatem, no 30. 


\section{Summary}

\section{Jesus and the Feminine Genius. The Anthropological Relevance of the Encounters of Jesus with Women in the Fourth Gospel}

Pope John Paul II introduced the expression of the "Feminine Genius" in his Apostolic Letter Mulieris Dignitatem of 1988. If this characteristic belongs to all women in history, there must be traces of it in the Gospel. The article verifies that this is the case in the Gospel of John.

Indeed, taking a closer look to the different encounters between Jesus and individual women, we see that the latter have a specific influence on the action of Jesus and participate in a particular way in the mission of Jesus. Two key ideas can help us clarify in which way these women participate in Jesus' mission. The first is the fruitfulness of faith. Those who believe are born from God himself (1:13), through faith in Christ. This is particularly the case for the Samaritan woman (4:4-42). Her life changes when she comes progressively to faith in Christ: "could he be the Christ?" (4:29). The second key idea is the prophecy of the High Priest Caiaphas: "Jesus was to die for the nation and not for the nation only but also in order to gather into one the scattered children of God." (11:51-52). Again, the Samaritan woman can serve as an example. She goes back to her town and brings her fellow Samaritans to faith in Jesus (4:39: "Many of that town believed in him"). They represent the first fruits of the great eschatological harvest, the gathering of those who believe in Jesus.

Both ideas can shine a light on the specific mission of women in the Fourth Gospel. From Mary in Cana or at the foot of the cross to Mary Magdalene at the tomb, from the Samaritan woman to the adulterous woman and the sisters Martha and Mary, they all influence Jesus in his specific mission of arousing faith and gathering the scattered children of God.

These encounters will help us to understand more concretely what John Paul II meant by Feminine Genius and what the role of women in the mission of the Church could be now.

Keywords: feminine genius, woman, man, gospel of John, John Paul II

Jezus i geniusz kobiecy.

Antropologiczne znaczenie spotkań Jezusa z kobietami w czwartej Ewangelii

Papież Jan Paweł II w swym liście apostolskim z 1988 roku Mulieris Dignitatem wprowadził określenie „kobiecego geniuszu”. Jeżeli cecha ta wspólna jest wszystkim kobietom na przestrzeni całej historii ludzkości, to z całą pewnością istnieją jej 
ślady na kartach Ewangelii. W przypadku Ewangelii św. Jana jest tak w istocie, czego potwierdzenie opisuje niniejszy artykuł.

Rzeczywiście przyglądając się bliżej różnym spotkaniom pomiędzy Jezusem a kobietami, zaobserwować możemy, iż miały one specyficzny wpływ na Jego działania, a co za tym idzie uczestniczyły w szczególny dla siebie sposób w misji Jezusa.

Pomocą do wyjaśnienia sposobu, w jaki kobiety te uczestniczyły w misji Jezusa, niech będą dwie kluczowe koncepcje. Pierwsza z nich, to płodność wiary. Ci, którzy uwierzyli, narodzili się z samego Boga $(1,13)$, przez wiarę w Jezusa Chrystusa. Przykładem tego może być Samarytanka (4, 4-42). Jej życie zmienia się, gdy stopniowo dochodzi do wiary w Chrystusa: „czyż On nie jest Mesjaszem?" $(4,29)$.

Drugą kluczową koncepcją jest proroctwo najwyższego kapłana Kajfasza „Jezus miał umrzeć za naród, a nie tylko za naród, ale także, „,by rozproszone dzieci Boże zgromadzić w jedno" (11,51-52). Tutaj podobnie, Samarytanka może nam posłużyć za przykład. Samarytanka wraca do swojego miasta i przyprowadza jego mieszkańców do wiary w Jezusa ( 4,39 ; ,wielu Samarytan z tego miasta zaczęło w Niego wierzyć"). Stanowią oni pierwsze owoce eschatologicznego żniwa: zgromadzenie tych, którzy wierzą w Jezusa.

Obie te koncepcje rzucają światło na szczególną misję kobiet w czwartej Ewangelii. Począwszy od Matki Boskiej na weselu w Kanie Galilejskiej czy u stóp krzyża aż do Marii Magdaleny przy grobie, od Samarytanki aż do jawnogrzesznicy czy sióstr Marty i Marii, kobiety, te miały wpływ na Jezusa w Jego misji wzbudzania wiary i gromadzenia rozproszonych dzieci Bożych.

Słowa kluczowe: kobiecy geniusz, kobieta, mężczyzna, Ewangelia św. Jana; Jan Paweł II

\section{Bibliography}

Gerl-Falkovitz H. B., Frau-Männin-Menschin. Zwischen Feminismus und Gender, Kevelaer 2009.

Gourgues M., Marie, la "femme" et la "mère" en Jean, "Nouvelle Revue Théologique" 108 (1986), p. 174-191.

Hennaux J.-M., Le sacerdoce. Humain et divin, masculin et féminin, Paris 2018 (Cahiers de la NRT).

John Paul II, Apostolic Letter Mulieris Dignitatem (15.8.1988).

Kubacki M.-L., Il lavoro (quasi) gratuito delle suore, "L'Osservatore Romano" (1.3.2018) http://www.osservatoreromano.va/it/news/il-lavoro-quasi-gratuito-delle-suore (1.3.2018.).

Lefebvre P., de Montalambert V., Un homme, une femme et Dieu, Paris 2007.

Leon-Dufour X., Lecture de l'évangile selon Jean, vol. 1, Paris 1988.

Marzotto D., Pietro e Maddalena. Il Vangelo corre a due voci, Milano 2010. 
Monnier P., Jésus ressuscité, le prophète plus grand que Moïse. Lecture de Jn 21, 1-14, "Nouvelle Revue Théologique" 139 (2017), p. 3-14.

Quéré F., Les femmes de l'évangile, Paris 1982.

Simoens Y., Selon Jean. 2. Une interprétation, Bruxelles 1997.

Stein E., Die Frau. Fragestellungen und Reflexionen, Freiburg-Basel-Wien $2002^{2}$ (Edith Stein Gesamtausgabe, 13). 